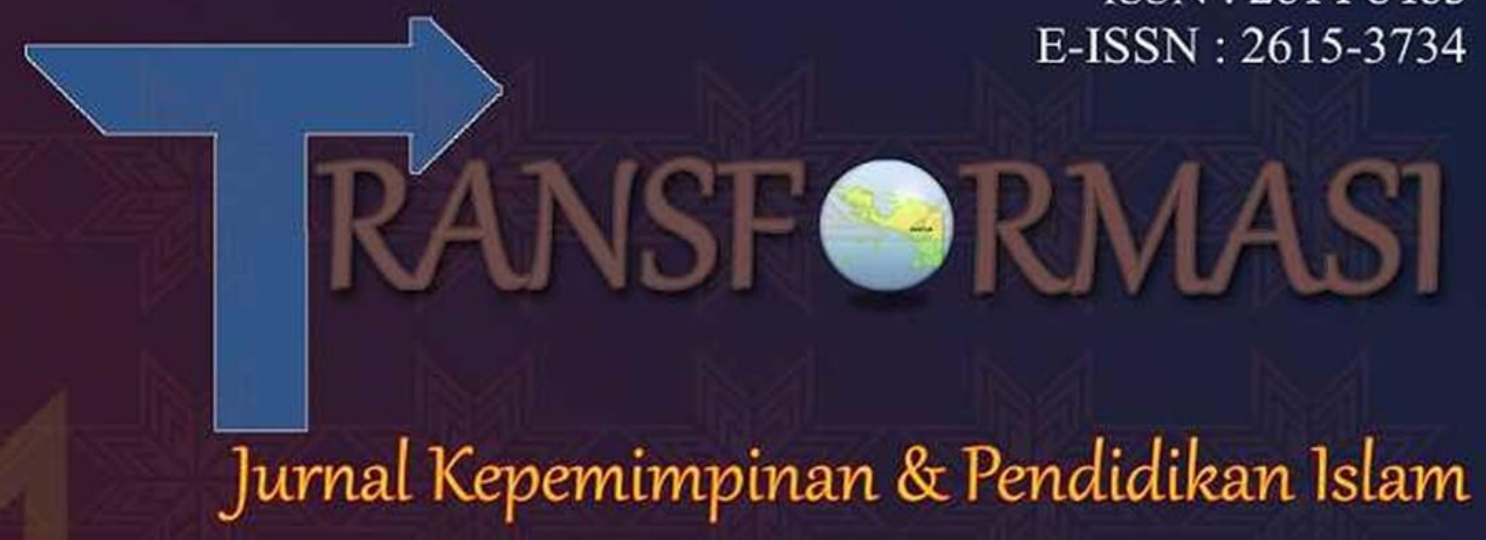

\title{
VOLUME 1 NOMOR 2 JUNI 2018
}

CURRICULUM 2013 IN RELATION TO EDUCATION FOR SUSTAINABLE DEVELOPMENT IN NDONESIA: WHY, WHAT, AND HOW

\section{Rusli}

TINJAUAN KRITIS NILAI-NILAI PENDIDIKAN KARAKTER SEBAGAI MEDIA PENDIDIKAN POLITIK BAGI KADER PARPOL

\section{Hasan Hanafi}

PEMIKIRAN POLITIK DAN PEMERINTAHAN IKHWANUL MUSLIMIN PASCA MUSIM SEMI ARAB

\section{Syawaluddin}

OPTIMALISASI MANAJEMEN KEUANGAN PENDIDIKAN DI INDONESIA

\section{Hikmah}

PEMBELAJARAN BAHASA INGGRIS BERDASARKAN PENDEKATAN SAINTIFIK KURIKULUM 2013 DI KELAS VII MTS DDI JOLLE

Kasmah \& Syamsir Bin Rukka

PENDIDIKAN ISLAM DI INDONESIA DALAM PERSPEKTIF POLITIK

\section{Restu Rahmawati}




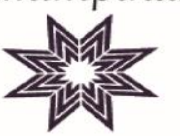

\title{
PEMBELAJARAN BAHASA INGGRIS BERDASARKAN PENDEKATAN SAINTIFIK KURIKULUM 2013 DI KELAS VII MTS DDI JOLLE
}

\section{Kasmah \& Syamsir Bin Rukka}

Guru Bahasa Inggris MTs DDI Jolle \&

Jurusan Bahasa Inggris, Fakultas Pendidikan Agama Islam

Institut Agama Islam Negeri Fattahul Muluk Papua

r $\underline{\text { Kasmahlutfy80@gmail.com \& david syam@,hotmail.com }}$

\begin{abstract}
:
This research was aimed at investigating (1) lesson plan based on scientific approach as curriculum 2013 in the class VII of MTs Negeri DDI Jolle; (2) the implementation of English learning based on saintific approach; (3) the model of the learning in the curriculum 2013; (4) the use of instructional media; and (5) the assessment process based on curriculum 2013. This research was qualitative descriptive. Data were collected by using documentation, observation, and interview. The results showed that (1) lesson plan used in english learning in the class VII of MTs DDI Jolle accordance to Ministry Rule (Permen) No. 58, 2014; (2) the learning process bas reflected the achievement of KI-1, KI-2, KI-3, and KI-4; (3) English learning based on a scientific approach covering five learning experience of observing, questioning, experimenting, associating and communicating feasible although it still not optimal; (4) the use of instructional media is not maximized because infocus display less clear and not attractive; (5) the assessment consist of attitude, knowledge, and skill. Based on this research suggested to the teachers to familiarize themselves communicating in English. Principals should consider the availability of instructional media. Other researchers are advised to conduct research related to the assessment process in curriculum 2013.
\end{abstract}

Keywords. English Learning, Curriculum 2013, Lesson Plan (RPP), Scientific Approach,Instructutional Media. 
TRANSFORMASI: Jurnal Kepemimpinan Dan Pendidikan Islam

Volume: 1 Nomor 2 ,Juni 2018

Pembelajaran Bahasa Inggris Berdasarkan ...., H. 54-70

\section{PENDAHULUAN}

Kasmah

Penelitian ini berawal dari sebuah berita di Kompas.com yang mengatakan bahwa "pada tanggal 5 Desember 2014 Menteri Kebudayaan dan Pendidikan Dasar Menengah, Anies Baswedan memutuskan untuk menghentikan Kurikulum 2013". Tetapi pada kenyataannya masih banyak sekolah yang menerapkan kurikulum 2013 tersebut. Hal ini terjadi karena Menteri Kebudayaan dan Pendidikan Dasar Menengah Anies Baswedan mengatakan bahwa "penerapan Kurikulum 2013 (K13) di sekolah-sekolah memang sudah resmi dihentikan. Namun, ia tidak melarang bagi sekolah yang tetap ingin menerapkan kurikulum tersebut" (Kompasiana.com, 7 Desember 2014).

Karena ketidakjelasan kurikulum 2013 dan membingungkan banyak orang, maka peneliti ingin mencari lebih banyak lagi informasi tentang tarik ulur implementasi kurikulum 2013 tersebut. Berdasarkan dari sebuah berita di Antara news.com dikatakan bahwa sewaktu Muhammad Nuh menjadi Kemendikbud, beliau menerapkan implementasi kurikulum 2013 pada 6.221 sekolah percontohan pada tahun ajaran 2013/2014, tepatnya April 2013. Kemudian pada tahun ajaran 2014/2015 langsung diberlakukan kurikulum 2013 untuk seluruh sekolah di Indonesia. Kemudian pada saat kurikulum 2013 berlaku untuk seluruh sekolah di Indonesia, Mendikbud Anies Baswedan mengeluarkan putusan pada Desember 2014, untuk kembali pada kurikulum 2006 atau Kurikulum Tingkat Satuan Pendidikan (KTSP) (Antara news. com, 13 Desember 2014).

Berdasarkan data lapangan yang peneliti peroleh dari Kepala MTs DDI Jollebahwa "MTs DDI Jolle bukan salah satu sekolah percontohan dalam penerapan implementasi kurikulum 2013 yang total sekolahnya berjumlah 6.221 sekolah se- Indonesia. Tetapi MTs DDI Jolle telah menerapkan implementasi kurikulum 2013 untuk semua mata pelajaran bagi kelas VII, mata pelajaran pendidikan Agama dan Bahasa Arab bagi kelas VIII dan IX sejak tahun pelajaran 2015/2016 sesuai dengan keputusan dari Kementrian Agama RI melalui Dirjen Pendis dengan surat edaran Kakanwil Sumatera Barat" (Hasil Wawancara dengan Kepala MTs DDI Jolle, 5 januari 2019).

Kurikulum 2013 dibentuk untuk meningkatkan kualitas potensi peserta didik. Hal ini sejalan dengan dibentuknya Undang- Undang no 20 tahun 2003 yang menghendaki proses pembelajaran diselenggarakan secara interaktif, menyenangkan, menantang, inspiratif, memotivasi peserta didik untuk berpartisipasi aktif, serta memberikan ruang yang cukup bagi prakarsa, 
kreativitas, dan kemandirian sesuai dengan bakat, minat, kemampuan, dan perkembangan fisik serta psikologis peserta didik. Berdasarkan Undang-Undang No. 20 tahun 2003 tersebut yang dituntut aktif dalam proses belajar mengajar adalah peserta didik. Lalu bagaimana caranya membimbing peserta didik untuk bisa aktif dalam proses belajar mengajar khususnya dalam pembelajaran Bahasa Inggris jika masih ada peserta didik itu sendiri yang belum mengenal Bahasa Inggris di sekolah lanjutan karena belum pernah mempelajarinya di Sekolah Dasar. Informasi ini peneliti peroleh melalui wawancara dengan Ibu Yelvira 5 Januari 2016 sebagai guru Bahasa Inggris di kelas VII MTs DDI Jolle yang mengatakan bahwa "untuk berkomunikasi dengan bahasa inggris itu agak sulit karena masih ada peserta didik yang belum tahu sama sekali dengan pelajaran Bahasa Inggris seperti lulusan dari SD-SD di pedalaman yang baru mengenal bahasa inggris di kelas MTs DDI Jolle ".

Proses belajar Bahasa Inggris di sekolah telah terbukti menghasilkan sedikit lulusan sekolah menengah yang memiliki kemampuan berbicara, menyimak, membaca, dan menulis dalam bahasa Inggris untuk tujuan nyata. Nilai tinggi dalam ulangan, tes dan ujian ternyata tidak menjamin bahwa siswa mampu berkomunikasi dengan baik dalam Bahasa Inggris dalam arti yang sebenarnya. Oleh karena itu, kita harus berani mengatakan bahwa pasti ada yang salah dengan tradisi pembelajaran selama ini, dan tidak ragu-ragu mencoba melakukan pendekatan lain, bahkan meskipun pendekatan tersebut belum pernah sama sekali dilakukan sebelumnya di sekolah. Kita harus mau mengubah mind set kita untuk lebih akomodatif terhadap pemikiran yang inovatif dan lebih bermanfaat bagi peningkatan kualitas proses dan hasil belajar siswa (Permendikbud, Nomor 58 tahun 2014).

Dengan berbagai permasalahan tentang implementasi kurikulum $2013 \mathrm{di}$ atas, menurut peneliti penting diadakan penelitian mengenai penerapan kurikulum 2013 dalam pembelajaran Bahasa Inggris di MTs DDI Jolle ini khususnya dalam proses belajar mengajar di kelas. Kajian dalam penelitian ini didukung dengan temuan terdahulu oleh Bintari, Sudiana, I Nyoman dan Ida (2014) yang menyimpulkan bahwa (1) perencanaan pembelajaran Bahasa Indonesia berdasarkan pendekatan saintifik sesuai Kurikulum 2013 di kelas VII MTs DDI Jolle Amlapura menunjukkan bahwa kegiatan pendekatan saintifik direncanakan pada komponen langkah- langkah pembelajaran; (2) pelaksanaan pembelajaran dalam pendekatan saintifik yaitu mengamati, menanya, mencoba, mengasosiasi, dan mengomunikasikan tampak dalam kegiatan pembelajaran dan terlaksana dalam dua kali pertemuan; (3) evaluasi pembelajaran Bahasa 
TRANSFORMASI: Jurnal Kepemimpinan Dan Pendidikan Islam

Volume: 1 Nomor 2 ,Juni 2018

Pembelajaran Bahasa Inggris Berdasarkan ...., H. 54-70

Kasmah

Indonesia berupa penilaian pengetahuan dan penilaian keterampilan; dan (4) kendala-kendala yang dialami guru adalah ketidaksesuaian antara waktu dengan materi pembelajaran. Materi pembelajaran sangat kompleks sedangkan waktu yang tersedia sangat terbatas. Kendala lain yaitu contoh-contoh yang disajikan pada buku pegangan siswa tidak kontekstual sehingga menyulitkan siswa menyerap materi pembelajaran.

Penelitian yang dilakukan oleh peneliti di sini lebih menitikberatkan penelitian pada proses pembelajaran berdasarkan pendekatan saintifik di kelas. Sedangkan penelitian Bintari, Sudiana, I Nyoman dan Ida (2014) lebih menitikberatkan pada perbandingan RPP pada silabus dengan RPP yang disusun oleh guru. Persamaan hasil penilitan terletak pada temuan tentang pelaksanaan pembelajaran Bahasa Indonesia berdasarkan pendekatan saintifik sesuai Kurikulum 2013 dengan pendekatan saintifik yaitu mengamati, menanya, mencoba, mengasosiasi, dan mengomunikasikan tampak dalam kegiatan pembelajaran.

Selanjutnya penelitian Sukirno (2014) yang menyimpulkan bahwa (1) implementasi Kurikulum 2013 dalam kegiatan belajar mengajar Bahasa Inggris di MTs Jolle belum sepenuhnya berjalan dengan baik. Para guru belum sepenuhnya melaksanakan pendekatan saintifik dan penilaian otentik. Hal ini disebabkan oleh pemahaman guru terhadap kurikulum yang masih kurang dan keterbatasan waktu mengajar mereka; (2) dalam proses pembelajaran dengan menerapkan Kurikulum 2013, guru-guru Bahasa Inggris menghadapi beberapa kesulitan. Kesulitan-kesulitan tersebut di antaranya adalah waktu jam pelajaran yang relatif sedikit untuk pembelajaran dengan pendekatan saintifik dan penilaian otentik, masih ada siswa yang motivasi belajarnya rendah, dan kemampuan guru yang berbeda-beda terhadap pemahaman Kurikulum 2013; dan (3) guru-guru Bahasa Inggris melakukan berbagai usaha untuk mengatasi kesulitan yang dihadapinya. Usaha-usaha tersebut di antaranya adalah dengan menggunakan cara mengajar yang interaktif dan mengikuti berbagai pelatihan dan workshop yang berkaitan dengan Kurikulum 2013 di MGMP sekolah maupun di kabupaten.

Penelitian Sukirno (2014) tersebut selain mengkaji tentang implementasi kurikulum 2013 dalam kegiatan belajar mengajar Bahasa Inggris di kelas juga membahas tentang kesulitan-kesulitan yang dihadapi oleh guru- guru dalam proses pembelajaran dengan menerapkan kurikulum 2013 serta usaha- usaha yang dilakukan oleh guru-guru dalam mengatasi kesulitan-kesulitan yang dihadapi dalam implementasi kurikulum 2013. Sementara dalam penelitian ini peneliti lebih fokus pada proses belajar mengajar berdasarkan pendekatan 
TRANSFORMASI: Jurnal Kepemimpinan Dan Pendidikan Islam

Volume: 1 Nomor 2 ,Juni 2018

Pembelajaran Bahasa Inggris Berdasarkan ...., H. 54-70

Kasmah

saintifik di kelas dan peneliti juga membahas tentang RPP. Persamaan penelitian ini dengan penelitian Sukirno (2014) terletak pada pendekatan saintifik dalam pembelajaran Bahasa Inggris sesuai dengan kurikulum 2013.

Sebagaimana amanat dari Undang- Undang Dasar 1945 yang mengatakan bahwa pembentukan Pemerintah Negara Indonesia yaitu antara lain untuk mencerdaskan kehidupan bangsa. Untuk mewujudkan upaya tersebut Undang-Undang Dasar 1945 pasal 31 ayat 3 memerintahkan agar Pemerintah mengusahakan dan menyelenggarakan satu sistem pendidikan nasional yang meningkatkan keimanan dan ketakwaan serta akhlak mulia dalam rangka mencerdaskan kehidupan bangsa yang diatur dengan undang-undang (Kemendikbud, 2012). Perwujudan dari amanat Undang-Undang Dasar 1945 yaitu dengan diberlakukannya Undang-Undang Nomor 20 tahun 2003 yang berbunyi "pendidikan adalah usaha sadar dan terencana untuk mewujudkan suasana belajar dan proses pembelajaran agar peserta didik secara aktif mengembangkan potensi diri, kepribadian, kecerdasan, akhlak mulia, serta keterampilan yang diperlukan dirinya, masyarakat, bangsa dan negara" (Kemdikbud, 2012).

Untuk mewujudkan Undang-Undang Nomor 20 tahun 2003 tersebut di atas, dibentuklah suatu kurikulum. Pada dasarnya kurikulum merupakan salah satu unsur sumber daya pendidikan yang memberikan kontribusi signifikan untuk mewujudkan proses berkembangnya kualitas potensi peserta didik. Kurikulum adalah seperangkat rencana dan pengaturan mengenai tujuan, isi dan bahan pelajaran serta cara yang digunakan sebagai pedoman penyelenggaraan kegiatan pembelajaran untuk mencapai tujuan pendidikan tertentu (UU Nomor 20 tahun 2003; PP Nomor 19 tahun 2005). Kurikulum pada dasarnya merupakan perencanaan menyeluruh yang mencakup kegiatan dan pengalaman yang perlu disediakan dan memberikan kesempatan secara luas bagi siswa untuk belajar (Bintari, Sudiana, I Nyoman dan Ida, 2014, Hariyanto, 2014).

Dari pendapat di atas dapat disimpulkan bahwa kurikulum merupakan perencanaan dan pengaturan dalam kegiatan pembelajaran yang dijadikan sebagai pedoman dalam pelaksanaan kegiatan pendidikan. Bisa juga dikatakan bahwa kurikulum itu memuat apa yang seharusnya diajarkan oleh guru kepada peserta didiknya.

Kurikulum 2013 bertujuan untuk mempersiapkan manusia Indonesia agar memiliki kemampuan hidup sebagai pribadi dan warga negara yang beriman, produktif, kreatif, inovatif, dan afektif serta mampu berkontribusi pada kehidupan bermasyarakat, berbangsa, bernegara, dan peradaban dunia 
TRANSFORMASI: Jurnal Kepemimpinan Dan Pendidikan Islam

Volume: 1 Nomor 2 ,Juni 2018

Pembelajaran Bahasa Inggris Berdasarkan ...., H. 54-70

Kasmah

(Permendikbud No. 58 tahun 2014). Dalam konsep kurikulum 2013 dijelaskan bahwa pembelajaran merupakan suatu proses pengembangan potensi dan pembangunan karakter setiap peserta didik sebagai hasil dari sinergi antara pendidikan yang berlangsung di sekolah, keluarga dan masyarakat. Proses tersebut memberikan kesempatan kepada peserta didik untuk mengembangkan potensi mereka menjadi kemampuan yang semakin lama semakin meningkat dalam sikap (spiritual dan sosial), pengetahuan, dan keterampilan yang diperlukan dirinya untuk hidup dan untuk bermasyarakat, berbangsa, serta berkontribusi pada kesejahteraan hidup umat manusia (Kemdikbud, 2012).

Untuk mencapai kualitas yang telah dirancang dalam dokumen kurikulum, kegiatan pembelajaran perlu menggunakan prinsip sebagai berikut (1) peserta didik difasilitasi untuk mencari tahu; (2) peserta didik belajar dari berbagai sumber belajar; (3) proses pembelajaran menggunakan pendekatan ilmiah; (4) pembelajaran berbasis kompetensi; (5) pembelajaran terpadu; (6) pembelajaran yang menekankan pada jawaban divergen yang memiliki kebenaran multi dimensi; (7) pembelajaran berbasis keterampilan aplikatif; (8) peningkatan keseimbangan, kesinambungan, dan keterkaitan antara hard-skills dan soft-skills; (9) pembelajaran yang mengutamakan pembudayaan dan pemberdayaan peserta didik sebagai pembelajar sepanjang hayat; (10) pembelajaran yang menerapkan nilai- nilai dengan memberi keteladanan (ing ngarsosung tulodo), membangun kemauan (ing madyo mangun karso), dan mengembangkan kreativitas peserta didik dalam proses pembelajaran (tut wuri bandayani); (11) pembelajaran yang berlangsung di rumah, di sekolah, dan di masyarakat; (12) pemanfaatan teknologi informasi dan komunikasi untuk meningkatkan efisiensi dan efektivitas pembelajaran; (13) pengakuan atas perbedaan individual dan latar belakang budaya peserta didik; dan (14) suasana belajar menyenangkan dan menantang (Permendikbud Nomor 103 tahun 2014).

Pada implementasi Kurikulum 2013 sangat disarankan menggunakan model- model pembelajaran discovery learning, project based learning dan problem based learning. Pada setiap model tersebut dapat dikembangkan sikap, pengetahuan, dan keterampilan (Permendikbud, Nomor 58 tahun 2014). Para peserta didik dituntut aktif untuk mendapatkan konsep yang dapat diterapkan dengan jalan memecahkan masalah, peserta didik akan mengeksplorasi sendiri konsep-konsep yang harus mereka kuasai, dan peserta didik diaktifkan untuk bertanya dan beragumentasi melalui diskusi, mengasah keterampilan investigasi, dan menjalani prosedur kerja ilmiah lainnya (Sari dan Purtadi, 2010, Fitria, Resti. Abdullah, A. Gafar, Hakim. D. Lukman, 2013). 
TRANSFORMASI: Jurnal Kepemimpinan Dan Pendidikan Islam

Volume: 1 Nomor 2 ,Juni 2018

Pembelajaran Bahasa Inggris Berdasarkan ...., H. 54-70

Kasmah

Kurikulum 2013 menggunakan modus pembelajaran langsung (direct instructional) dan tidak langsung (indirect instructional). Pembelajaran langsung adalah pembelajaran yang mengembangkan pengetahuan, kemampuan berpikir dan keterampilan menggunakan pengetahuan peserta didik melalui interaksi langsung dengan sumber belajar yang dirancang dalam silabus dan RPP. Dalam pembelajaran langsung peserta didik melakukan kegiatan mengamati, menanya, mengumpulkan informasi/mencoba, menalar/mengasosiasi, dan mengomunikasikan. Pembelajaran langsung menghasilkan pengetahuan dan keterampilan langsung, yang disebut dengan dampak pembelajaran (instructional effect) (Permendikbud Nomor 103 tahun 2014). Pengembangan RPP dalam kurikulum 2013 dapat dilakukan oleh guru secara mandiri dan/atau berkelompok di sekolah/madrasah dikoordinasi, difasilitasi, dan disupervisi oleh kepala sekolah/madrasah. Pengembangan RPP dapat juga dilakukan oleh guru secara berkelompok antar sekolah atau antar wilayah dikoordinasi, difasilitasi, dan disupervisi oleh dinas pendidikan atau kantor kementerian agama setempat (Permendikbud Nomor 103 tahun 2014).

Penelitian ini adalah penelitian kualitatif dengan menggunakan instrumen observasi, dokumentasi, dan wawancara (Emzir, 2011). Metode observasi peneliti gunakan untuk mengamati secara langsung proses pembelajaran Bahasa Inggris di kelas VII MTs DDI Jolle berdasarkan kurikulum 2013. Fokus peneliti adalah penerapan pembelajaran Bahasa Inggris berdasarkan pendekatan saintifik di kelas. Menurut Sukmadinata (2006) observasi merupakan suatu teknik atau cara mengumpulkan data dengan jalan mengadakan pengamatan terhadap kegiatan yang sedang berlangsung.

Metode dokumentasi digunakan untuk mengumpulkan data tentang perencanaan pembelajaran Bahasa Inggris sesuai dengan Kurikulum 2013 di kelas MTs DDI Jolle. Pengumpulan data dengan metode dokumentasi dilakukan dengan mengumpulkan perangkat pembelajaran berupa silabus dan Rencana Pelaksanaan Pembelajaran (RPP) yang dibuat guru sebelum melaksanakan pembelajaran di kelas. Selain mengamati langsung peneliti juga mengambil rekaman video selama proses pembelajaran tersebut berlangsung untuk satu kali pertemuan.

Metode wawancara peneliti gunakan untuk mengumpulkan data mengenai tahapan yang dilalui MTs Negeri Padang L uar dalam mengimplementasikan kurikulum 2013 sesuai dengan keputusan dari Kementrian Agama RI melalui Dirjen Pendis dengan surat edaran Kakanwil Sumatera Barat. Pihak yang diwawancarai adalah K epala Madrasah. K emudian 
TRANSFORMASI: Jurnal Kepemimpinan Dan Pendidikan Islam

Volume: 1 Nomor 2 ,Juni 2018

Pembelajaran Bahasa Inggris Berdasarkan ...., H. 54-70

Kasmah

wawancara kedua peneliti lakukan untuk mengumpulkan data mengenai proses pembuatan RPP dan kendala yang dihadapi dalam penerapan kurikulum 2013. Pihak yang diwawancarai adalah gur u mata pelajaran Bahasa Inggris kelas MTs DDI Jolle .

Kemudian wawancara ketiga peneliti lakukan untuk tambahan pengumpulan data mengenai pemilihan model pembelajaran yang terdapat dalam kurikulum 2013, media pembelajaran dan proses penilaian. Pihak yang diwawancarai adalah guru mata pelajaran Bahasa Inggris kelas VII MTs DDI Jolle. Menurut Sudjana (2000) wawancara adalah proses pengumpulan data atau informasi melalui tatap muka antara pihak penanya (interviewer) dengan pihak yang ditanya atau penjawab. Metode wawancara yang digunakan dalam penelitian ini adalah wawancara tidak terstruktur. Data yang diperoleh melalui metode wawancara ini juga untuk melengkapi data yang diperoleh melalui metode observasi, sehingga data yang diperoleh lebih lengkap dan mendalam. Dengan demikian, metode wawancara ini merupakan triangulasi pengumpulan data atas data observasi. Menurut Moleong (2005) triangulasi adalah teknik pemeriksaan keabsahan data yang memanfaatkan sesuatu yang lain. Teknik triangulasi yang paling banyak digunakan ialah pemeriksaan melalui sumber lainnya.

\section{PEMBAHASAN}

\section{A. PENDEKATAN SAINTIFIK DAN MEDIA PEMBELAJARAN}

Pembelajaran adalah proses interaksi antar peserta didik, antara peserta didik dengan tenaga pendidik dan sumber belajar pada suatu lingkungan belajar. Indikator pencapaian kompetensi adalah: (a) perilaku yang dapat diukur dan/atau diobservasi untuk kompetensi dasar (KD) pada kompetensi inti (KI)-3 dan KI-4; dan (b) perilaku yang dapat diobservasi untuk disimpulkan sebagai pemenuhan KD pada KI-1 dan KI-2, yang kedua-duanya menjadi acuan penilaian mata pelajaran. Uraian tentang Kompetensi Inti dan Kompetensi Dasar pada mata pelajaran Bahasa Inggris untuk jenjang SMP/MTs kelas VII dapat dilihat pada Permendikbud Nomor 58 tahun 2014.

Media pembelajaran merupakan alat yang digunakan dalam pembelajaran, meliputi alat bantu guru dalam mengajar serta sarana pembawa pesan dari sumber belajar ke penerima pesan belajar (peserta didik). Sebagai penyaji dan penyalur pesan, media belajar dalam hal-hal tertentu bisa mewakili guru menyajiakan informasi belajar kepada peserta didik (Permendikbud, 
Nomor 58 tahun 2014).

Terdapat beberapa jenis media dan sumber belajar yang dapat digunakan dalam proses pembelajaran Bahasa Inggris. Media dan sumber belajar yang ada diharapkan dapat membantu peserta didik dalam memahami proses pembelajaran Bahasa Inggris secara lebih kontekstual. Dalam hal ini, perlu diperhatikan sejak awal bahwa media maupun sumber belajar yang ada hanyalah sebagai alat bantu, sedangkan fokus utama dalam pembelajaran Bahasa adalah sebuah komunikasi, baik itu merupakan komunikasi interpersonal, transaksional, maupun fungsional secara lisan dan juga tulisan (Permendikbud, Nomor 58 tahun 2014).

Dalam hal pemanfaatan teknologi, komputerisasi menjadi salah satu sumber belajar yang diharapkan dapat membantu guru maupun peserta didik dalam melaksanakan proses pembelajaran. Penggunaan OHP maupun infocus sudah umum dilaksanakan di banyak sekolah. Selain itu, media internet pun dapat digunakan dalam mengoptimalisasi proses pembelajaran Bahasa Inggris. Terdapat banyak sumber belajar yang dapat kita temukan melalui internet. Namun, dalam hal ini guru tetap diharapkan mampu membantu mengarahkan peserta didik untuk memilih dan mensortir informasi yang diperoleh melalui internet (Permendikbud Nomor 58 tahun 2014).

\section{B. PENILAIAN HASIL BELAJAR}

Penilaian hasil belajar peserta didik adalah penilaian terhadap pencapaian Kompetensi Inti dan Komptensi Dasar yang diperoleh peserta didik setelah mengalami suatu proses pembelajaran yang meliputi kompetensi sikap, pengetahuan, keterampilan, dan kemampuan belajar yang dilakukan secara berimbang sehingga dapat digunakan untuk menentukan posisi setiap peserta didik terhadap standar yang telah ditetapkan (Permendikbud Nomor 58 tahun 2014).

Kurikulum 2013 menerapkan penilaian autentik untuk menilai kemajuan belajar peserta didik yang meliputi sikap, pengetahuan, dan keterampilan. Penilaian otentik adalah pendekatan dan instrumen asesmen yang memberikan kesempatan yang luas kepada peserta didik untuk menerapkan pengetahuan, ketrampilan, dan sikap yang sudah dimilikinya dalam bentuk tugas seperti berbicara, mendengar, membaca dan menulis dalam dunia nyata, di sekolah dan di luar sekolah seperti bersosialisasi, presentasi, mengamati, sur vey, project, membuat multimedia, membuat laporan, diskusi kelas, dan memecahkan masalah (Permendikbud Nomor 58 tahun 2014). 


\section{MODEL PEMBELAJARAN KURIKULUM2013}

Pada awal pembelajaran tentang "description" guru menjelaskan aktivitas yang akan dilakukan dan hasil yang diharapkan. Dari cara mengajar ini terlihat bahwa guru menggunakan model pembelajaran problem based learning. Menurut Ibu Yelvira (guru Bahasa Inggris kelas MTs DDI Jolle, Pada Wawancara, 10 Januari 2019), pada model ini pembelajaran dimulai dengan menjelaskan aktivitas-aktivitas yang akan dilakukan peserta didik dan hasil yang diharapkan. Hal ini telah sesuai dengan Permen Nomor 58 tahun 2014 "pada model pembelajaran Problem Based Learning (PBL) dilakukan langkah pembelajaran yang mengorientasi peserta didik pada masalah. Pembelajaran dimulai dengan menjelaskan tujuan pembelajaran dan aktivitas-aktivitas yang akan dilakukan".

\section{RENCANA PELAKSANAAN PEMBELAJARAN (RPP)}

Menurut Keterangan dari Ibu Yelvira (Hasil Wawancara, 5 Januari 2019), penyusunan Rencana Pelaksanaan Pembelajaran (RPP) dilakukan oleh forum Musyawarah Guru Mata Pelajaran (MPGP) dalam hal ini adalah semua guru bidang studi Bahasa Inggris se-Tanah Datar. Penyusunan RPP tersebut berpedoman pada silabus yang telah dikembangkan oleh Kementrian Pendidikan dan Kebudayaan (Kemdikbud). Langkah ini telah sesuai dengan Peraturan Mentri Pendidikan dan Kebudayaan Republik Indonesia nomor 58 tahun 2014 tentang kurikulum 2013 Sekolah Menengah Pertama/Madrasah Tsanawiyah pada pasal 9 dikatakan bahwa silabus sebagaimana dimaksud pada ayat (1) digunakan oleh pendidik sebagai acuan dalam penyusunan Rencana Pelaksanaan Pembelajaran.

RPP yang telah dihasilkan oleh MPGP dibagikan kepada setiap guru mata pelajaran dalam hal ini guru bahasa inggris. Menurut Ibu Yelvira (Hasil Wawancara, 5 Januari 2019), RPP yang telah diperoleh oleh guru bidang studi boleh dilakukan perbaikan sesuai dengan kondisi peserta didik. Hal ini sejalan dengan pedoman pelaksanaan pembelajaran pada Pendidikan Dasar dan Pendidikan Menengah yang terdapat pada salinan lampiran peraturan menteri Pendidikan dan Kebudayaan Republik Indonesia Nomor 103 Tahun 2014 yang mengatakan bahwa penjabaran kegiatan pembelajaran yang ada pada silabus dalam bentuk yang lebih operasional berupa pendekatan saintifik disesuaikan dengan kondisi peserta didik dan satuan pendidikan termasuk penggunaan media, alat, bahan, dan sumber belajar.

Dalam RPP pembelajaran bahasa inggris di kelas VII MTs DDI Jolle 
mencakup 1) identitas madrasah, mata pelajaran, kelas, semester; 2) alokasi waktu; 3) KI, KD, indikator pencapaian kompetensi; 4) materi pembelajaran; 5) kegiatan pembelajaran; 6) penilaian dan 7) media/alat, bahan, dan sumber belajar. RPP tersebut telah sesuai dengan Peraturan Menteri Pendidikan dan Kebudayaan Republik Indonesia Nomor 58 Tahun 2014 tentang kurikulum 2013 Sekolah Menengah Pertama/Madrasah Tsanawiyah pada pasal 8 dikatakan bahwa Silabus sebagaimana dimaksud dalam Pasal 1 ayat (2) huruf c merupakan rencana pembelajaran pada suatu mata pelajaran yang mencakup Kompetensi Inti, Kompetensi Dasar, Materi Pembelajaran, Kegiatan Pembelajaran, Penilaian, Alokasi Waktu, dan Sumber Belajar

\section{PENDEKATAN SAINTIFIK DAN MEDIA PEMBELAJARAN}

Di awal pembelajaran guru meminta peserta didik untuk berdoa sebelum belajar, begitu juga pada akhir pembelajaran guru meminta peserta didik untuk mengucapkan hamdalah dan salam yang termasuk pada KI-1 yaitu kompetensi dasar yang harus ada pada setiap mata pelajaran. Sebagaimana yang dijelaskan oleh Ibu Yelvira (Hasil Wawancara, 5 Januari 2019) bahwa KI-1 menyangkut masalah spritual dan hal ini termasuk pada hubungan manusia dengan Allah atau disebut juga hablumminallah.

Pada tahap berdoa di awal pembelajaran dan membaca hamdalab pada akhir pembelajaran terlihat pencapaian Kompetensi Inti/KI-1 yang mana peserta didik dapat menghargai dan menghayati ajaran agama yang dianutnya. Untuk kompetensi Dasar/ KD nya yaitu mensyukuri kesempatan dapat mempelajari Bahasa Inggris sebagai bahasa pengantar komunikasi internasional yang diwujudkan dalam semangat belajar juga sudah tampak selama proses pembelajaran berlangsung terlihat dari semangat peserta didik dalam menjawab per tanyaan- pertanyaan yang diberikan oleh pendidik atau guru.

Untuk KI-2 ter cermin pada rasa kebersamaan dan kerja sama peser ta didik. Guru mendorong siswa untuk bisa bekerjasama dengan baik, membangun teamwork yang solid melalui pembentukan kelompok. Setiap kelompok terdiri dari 4 (empat) orang dan diberi tugas menceritakan tentang guru favorit mereka. Hasil kerja mereka ditulis pada kertas berukuran besar ditempel pada papan tulis dan masing- masing kelompok bergiliran membacakan hasil kerja mereka. Anggota kelompok lain mengkritik hasil kerja kelompok yang tampil (Hasil Observasi, 15 Januari 2019).

Kalau dilihat dari kegiatan kelompok bisa dikatakan bahwa kegiatan ini sudah termasuk kedalam KI-2 dan KD-nya yang termasuk dalam prilaku jujur, 
tanggung jawab, peduli, dan percaya diri. Tetapi untuk kategori disiplin dan santun belum bias tercapai seutuhnya karena masih ada peserta didik yang belum disiplin dalam berpakaian seperti memakai seragam putih pada hari Sabtu yang seharusnya berpakaian pramuka, juga masih ada peserta didik yang tanpa memakai alas kaki maju ke depan kelas. Kemudian dalam hal santun juga masih belum terpenuhi seutuhnya karena banyak dari peserta didik yang tidak menjawab salam dari temannya yang tampil di depan kelas. Setelah guru memberitahu tentang kewajiban menjawab salam baru semuanya serentak untuk menjawab salam (Hasil Observasi, 15 Januari 2019).

$\mathrm{K}$ etika pr oses belajar mengajar berlangsung guru menempelkan sebuah gambar sebagai objek yang akan dibahas. Guru memberi pertanyaan yang memancing peserta didik untuk ikut berpartisipasi aktif dalam pembelajaran. Peserta didik aktif dalam bertanya, berdiskusi dan menjawab pertanyaan guru. Pada proses pembelajaran

ini terlihat terpenuhinya KI-3 yaitu memahami ilmu pengetahuan berdasarkan rasa ingin tahunya. Dalam pembelajaran ini juga terpenuhi KD dari KI-3 yaitu peserta didik memahami fungsi sosial, struktur teks, dan unsur kebahasaan dari teks deskriptif dengan menyatakan tentang deskripsi orang yaitu publik figur (Hasil Observasi, 15 Januari 2019).

Pada pembelajaran selanjutnya guru membagi peserta didik menjadi 4 (empat) kelompok untuk menyusun teks atau menceritakan tentang guru favorit mereka, kemudian masing-masing anggota kelompok maju ke depan kelas untuk menampilkan hasil kerja mereka. Guru meminta anggota kelompok berbagi tugas, ada yang menjadi moderator, ada yang menjadi speaker atau yang membacakan hasil kerja mereka dan mendapat tugas menjawab pertanyaan dari anggota kelompok lain. Kegiatan ini termasuk pada K-I 4 dengan indikator menulis, membaca, menghitung, menggambar, dan mengarang. Terlihat juga pencapaian KD dari KI-4 dalam pembelajaran ini yaitu menyusun teks deskriptif lisan dan tulis, sangat pendek dan sederhana, tentang orang, dengan memperhatikan fungsi sosial, struktur teks, dan unsur kebahasaan, secara benar dan sesuai konteks (Hasil Observasi, 15 Januari 2019).

Pembelajaran Bahasa Inggris dengan pendekatan saintifik berdasarkan kurikulum 2013 di kelas VII MTs DDI Jolle juga sudah terlihat pada proses belajar mengajar. Pada pembelajaran bahasa inggris di kelas VII MTs DDI Jolle sudah mencakup kelima pengalaman belajar pada pendekatan saintifik tersebut sebagaimana yang dituntut oleh kurikulum 2013. Satu kali pertemuan selama $2 \mathrm{x}$ 40 menit guru memulai pembelajaran dengan menempelkan sebuah gambar 
TRANSFORMASI: Jurnal Kepemimpinan Dan Pendidikan Islam

Volume: 1 Nomor 2 ,Juni 2018

Pembelajaran Bahasa Inggris Berdasarkan ...., H. 54-70

Kasmah

public figure di papan tulis dan peserta didik diminta untuk mengamati gambar tersebut. Kegiatan ini pada pembelajaran dengan pendekatan saintifik termasuk pada langkah mengamati (observing).

Kemudian pada langkah selanjutnya guru meminta peserta didik untuk mengeluarkan pendapat mereka masing-masing terhadap gambar seorang public figure tersebut. Peserta didik bebas mengeluarkan pendapat mereka masingmasing. Pada proses belajar mengajar ini terjadi tanya jawab dan diskusi yang termasuk pada langkah menanya (questioning) pada pembelajaran dengan pendekatan saintifik.

Selanjutnya guru membagi peserta didik menjadi 4 (empat) kelompok yang masing-masing kelompok terdiri dari 4 (empat) orang. Mereka berdiskusi tentang guru favorit mereka dan mencari kalimat- kalimat yang tepat untuk menggambarkan sosok atau figur seorang guru favorit. Proses diskusi antara sesama peserta didik ini termasuk pada langkah mengumpulkan informasi/mencoba (experimenting).

Setelah berbagai informasi mereka dapatkan dari masing-masing anggota kelompok, peserta didik membuat tulisan atau cerita singkat tentang guru favorit mereka dalam Bahasa Inggris. Empat kelompok menghasilkan empat cerita pula dan hasil kerja mereka ditempel pada papan tulis (Hasil Studi Dokumentasi, 15 Januari 2019). Kegiatan ini termasuk pada langkah menalar/mengasosiasi (associating) pada pembelajaran dengan pendekatan saintifik.

Kemudian masing-masing kelompok tampil di depan kelas secara bergantian. Satu kelompok terdiri dari 4 (empat) orang. Mereka berbagi tugas menjadi moderator, speaker atau yang menyampaikan cerita singkat tersebut dan anggota lainnya yang akan menjawab pertanyaan dari kelompok lain. Kegiatan ini sudah termasuk pada langkah mengomunikasikan (communicating).

Pada proses pembelajaran Bahasa Inggris berdasarkan pendekatan saintifik di kelas VII MTs DDI Jolle sudah memenuhi tuntutan kurikulum 2013, tetapi masih kurang optimal dalam pemenuhan KI-2. Tampak pada terpenuhinya KI-1 dan KD, KI-2 dan KD tapi masih kurang dalam disiplin dan santun, KI-3 dan KD serta KI-4 dan KD. Semua langkah pembelajaran berdasarkan pendekatan saintifik yaitu mengamati (obser ving), menanya (questioning), mengumpulkan informasi/mencoba (experimenting ), menalar/mengasosiasi (associating) dan mengomunikasikan (communicating) juga sudah terpenuhi. Hanya saja dalam proses pembelajaran Bahasa Inggris tersebut guru lebih dominan memakai bahasa Indonesia dari pada Bahasa Inggris itu sendiri. Menurut Ibu Yelvira (Hasil Wawancara, 5 Januari 2019) hal tersebut 
TRANSFORMASI: Jurnal Kepemimpinan Dan Pendidikan Islam

Volume: 1 Nomor 2 ,Juni 2018

Pembelajaran Bahasa Inggris Berdasarkan ...., H. 54-70

Kasmah

disebabkan karena kelas VII merupakan kelas lanjutan dari Sekolah Dasar yang masih begitu minim akan pengetahuan tentang Bahasa Inggris, bahkan ada di antara peserta didik yang tidak mengenal Bahasa Inggris sama sekali sebelum mereka masuk ke MTs DDI Jolle. Jadi guru lebih dominan berkomunikasi dalam bahasa Indonesia supaya anak lebih mengerti dengan apa yang disampaikan oleh guru.

Keadaan yang terjadi di atas belum sejalan dengan tuntutan pembelajaran Bahasa Inggis sesuai dengan kurikulum 2013 yang tertuang dalam lampiran Permen Nomor 58 tahun 2014 yang mengatakan bahwa tujuan pembelajaran Bahasa Inggris bukan untuk pemahaman dan penerapan konsep, tetapi pembiasaaan melakukan tindakan dalam Bahasa Inggris untuk melaksanakan fungsi sosial. Dalam lampiran III Permen Nomor 58 tahun 2014 juga dikatakan bahwa pada kelompok keterampilan berbicara, seorang guru diharapkan dapat memberikan contoh yang baik dari segi pengucapan (pronunciation), intonasi (intonation), tekanan kata (word stress), kelancaran (fluency), maupun ketelitian (accuracy). Ketika guru sudah dapat memberikan contoh yang baik dalam berbicara, maka peserta didik pun akan dapat lebih cepat mengadopsi ketika berbicara dengan pihak lain.

Dalam proses pembelajaran gur u sudah memanfaatkan media pembelajaran berupa infocus. Guru melibatkan peserta didik menggunakan media pembelajaran dengan mengetik jawabannya di laptop dan ditampilkan melalui infocus (Hasil Observasi, 15 Januari 2019). Guru juga menempelkan foto seorang publik figur dipapan tulis untuk di deskripsikan bersama-sama. Hanya saja penggunaan media pembelajaran seperti infocus tidak terlaksana dengan maksimal karena kurang bersihnya tampilan infocus di papan tulis. Hendaknya disediakan sasaran infocus yang lebih bersih supaya tampilan jelas dan menarik. Selain itu guru dirasa tidak perlu menempelkan gambar di papan tulis karena guru bisa mengambil gambar tersebut dari laptop dan ditampilkan melalui infocus supaya tampilan gambar lebih besar, jelas dan menarik. Menurut Ibu Yelvira (Hasil Wawancara, 10 Januari 2019) selain infocus, biasanya juga menggunakan media lain seperti recorder, kartu bridge, CD ditampilkan lewat infocus sesuai dengan materi ajar. Hanya saja media pembelajaran yang tersedia di sekolah belum mencukupi.

\section{PENILAIAN HASIL BELAJAR}

Diakhir pembelajaran guru membagi kertas selembar kepada peserta didik yang berisikan soal tentang pembelajaran yang baru saja berlangsung. Hal 
TRANSFORMASI: Jurnal Kepemimpinan Dan Pendidikan Islam

Volume: 1 Nomor 2 ,Juni 2018

Pembelajaran Bahasa Inggris Berdasarkan ...., H. 54-70

Kasmah

ini dilakukan untuk penilaian pengetahuan peserta didik. Menurut Ibu Yelvira (Wawancara, 10 Januari 2016) penilaian terbagi pada kriteria penilaian sikap, pengetahuan dan keterampilan. Penilaian sikap dilakukan selama proses pembelajaran berlangsung, penilaian pengetahuan berdasarkan hasil tes tertulis, penilaian keterampilan berdasarkan praktik dalam bentuk speaking dan writing. Hal ini telah sejalan dengan lampiran III Permen Nomor 58 tahun 2014 yang terulis bahwa kompetensi sikap, pengetahuan, keterampilan, dan kemampuan belajar yang dilakukan secara berimbang sehingga dapat digunakan untuk menentukan posisi setiap peserta didik terhadap standar yang telah ditetapkan.

\section{KESIMPULAN}

Hasil penelitian tentang pembelajaran bahasa inggris berdasarkan pendekatan saintifik di kelas VII MTs DDI Jolle dapat kita simpulkan sebagai berikut 1) pemilihan model pembelajaran tergantung pada materi ajar; 2) RPP yang digunakan dalam pembelajaran Bahasa Inggris di kelas VII MTs DDI Jolle telah sesuai dengan Permen nomor 58 tahun 2014; 3) proses belajar mengajar telah mencerminkan pencapaian KI-1, KI-2, KI-3 dan KI-4; 4) pembelajaran Bahasa Inggris berdasarkan pendekatan saintifik di kelas VII MTs DDI Jolleyang meliputi lima pengalaman belajar yaitu observing, questioning, experimenting, associating, dan communicating dapat dilaksanakan walaupun masih belum maksimal karena komunikasi dalam proses belajar mengajar masih dominan dalam bahasa indonesia; 5) gur u mampu menggunakan media pembelajaran walaupun masih belum maksimal karena tampilan infocus kurang jelas dan kurang menarik; dan 6) penilaian yang dilakukan adalah penilaian sikap, pengetahuan dan keterampilan.

\section{DAFTAR PUSTAKA}

Antaranews.com, 13 Desember 2019. Jalan Tengah untuk. Kurikulum 2013. bttp:/ / wnw.antaranews.com/berita/469034/ jalan-tengah-untuk-kurikulum-2013

Bintari, N.L. Gede. Sudiana, R.R. I Nyoman, Putrayasa. Ida, Bagus. (2014). "Pembelajaran Bahasa Indonesia Berdasarkan Pendekatan Saintifik (Problem Based Learning) Sesuai Kurikulum 2013 di Kelas VII SMP Negri 2

Almapura". e- Journal Program Pascasarjana Universitas Pendidikan Ganesha Program Studi Pendidikan Bahasa Indonesia, Volume 3.

Dokumen Kurikulum 2013. (2012). Kementrian Pendidikan Dan Kebudayaan. 
TRANSFORMASI: Jurnal Kepemimpinan Dan Pendidikan Islam

Volume: 1 Nomor 2 ,Juni 2018

Pembelajaran Bahasa Inggris Berdasarkan H. $54-70$

Kasmah

Emzir. (2011). Metodologi Penelitian Kualitatif: Analisis Data. Jakarta: PT Raja Grafindo Persada.

Fitria, Resti. Abdullah, A. Gafar, Hakim. D.Lukman. (2013). "Pembelajaran Saintifik Elektronik Dasar Berorientasi Pembelajaran Berbasis Masalah”. Jurnal Invotec Program Studi Pendidikan Teknik Elektro FPTK UPI, Volume IX No.02, 165:178.

H ariyanto, Fitri Anggraini. (2014). "Meningkatkan Kemampuan Mahasiswa dalam Mengembangkan RPP Berdasarkan Kurikulum 2013 dengan Menggunakan 'Bloom's Taxonomy Cognitive Domain Learning Stages pada Mahasiswa Semester VI FKIP Bahasa Inggris Universitas Kanjuruhan Malang". Jurnal Inspirasi Pendidikan Universitas Kanjuruban Malang.

Kemdikbud (2015). Pembelajaran Dengan Pendekatan Saintifik. Jakarta: Kementerian Pendidikan dan Kebudayaan Direktorat Jenderal Pendidikan Dasar dan Menengah.

Kemdikbud. (2012). Undang-Undang Dasar 1945 pasal 31 ayat 3Kompasiana.com, 7 Desember 2019.

Penghentian Kurikulum 2013 hanya Sementara. https://www.google.com/ search?q=Mendikbud + Anies +

Moleong, Lexy J. (2005). Metodologi Penelitian Kualitatif. Bandung: Remaja Rosda Karya

Permendikbud Nomor 103Tahun 2014 (2014). Salinan Lampiran Peraturan Menteri Pendidikan dan Kebudayaan Republik Indonesia Nomor 103 Tahun 2014 Tentang Pembelajaran pada Pendidikan Dasar dan Pendidikan Menengah.

Permendikbud Nomor 58 Tahun 2014. (2014). Salinan Peraturan Menteri Pendidikan dan Kebudayaan Republik Indonesia Nomor 58 Tahun 2014 Tentang kurikulum 2013 Sekolah Menengah Pertama/Madrasah Tsanawiyah.

Peraturan Pemerintah Nomor 19 tahun 2005

Sari, Rr. Lis Permana. Purtadi, Sukisman. (2010). "Pembelajaran Kimia Tematik Pada Mata Kuliah Kimia Dasar sebagai Model Pembelajaran Berbasis Masalah". Cakerawala Pendidikan, November 2010, Th. XXIX, No. 3 
TRANSFORMASI: Jurnal Kepemimpinan Dan Pendidikan Islam

Volume: 1 Nomor 2 ,Juni 2018

Pembelajaran Bahasa Inggris Berdasarkan ...., H. 54-70

Kasmah

Sukmadinata, Syaodih Nana. 2006. Metode Penelitian Pendidikan. Bandung: Remaja Rosdakarya.

Sukirno, Sukirno (2014). Penerapan Kurikulum 2013 dalam Pembelajaran B ahasa I nggris di SMP 1 Kajen Pekalongan. UNY: S2 Thesis.

Undang-Undang Nomor 20 Tahun 2003 